\title{
BMJ Global Health The uses of knowledge in global health
}

\author{
Seye Abimbola (1) ${ }^{1,2}$
}

To cite: Abimbola S. The uses of knowledge in global health. BMJ Global Health 2021;6:e005802. doi:10.1136/ bmjgh-2021-005802

Received 23 March 2021 Accepted 23 March 2021
Check for updates

(c) Author(s) (or their employer(s)) 2021. Re-use permitted under CC BY-NC. No commercial re-use. See rights and permissions. Published by BMJ.

${ }^{1}$ School of Public Health, University of Sydney, Sydney, New South Wales, Australia

${ }^{2}$ Julius Global Health, University Medical Center, Utrecht University, Utrecht, The Netherlands

Correspondence to

Dr Seye Abimbola;

Seye.Abimbola@sydney.edu.au
If ...the problem of society is mainly one of rapid adaptation to changes in the particular circumstances of time and place... [then] the ultimate decisions must be left to the people who are familiar with these circumstances, who know directly of the relevant changes and of the resources immediately available to meet them. We cannot expect that this problem will be solved by first communicating all this knowledge to a central board which, after integrating all knowledge, issues its orders. We must solve [the problem] by some form of decentralization..

But the '[people] on the spot' cannot decide solely on the basis of [their] limited but intimate knowledge of the facts of [their] immediate surroundings. There still remains the problem of communicating to [them] such further information as [they need] to fit [their] decisions into the whole pattern of changes of the larger [...] system. How much knowledge [do they] need to do so successfully? Which of the events which happen beyond the horizon of [their] immediate knowledge are of relevance to [their] immediate decision, and how much of them need [they] know?

$$
\text { -F. A. Hayek (1899-1992) }{ }^{1}
$$

\section{INTRODUCTION}

Like any academic involved in global healthand especially as a journal editor-I am frequently called on to make judgements on research papers. ${ }^{2}$ Like anyone reading such papers, I rely on the declared aim, usually at the end of the introduction or background section. The declared aim can reveal whom we imagine we write for (ie, gaze or audience) and the standpoint from which we write (ie, pose or positionality). ${ }^{3}$ But much too often, it reads like an afterthought, as though it was written in pretence or in tenuous hope, like an item thrown aimlessly into deep space in the hope that it might hit a target called equity. The declared aim of research papers in global health often betrays a lack of collective sense or theory of how knowledge leads to equity - a theory to which we may align how we value, produce and use knowledge. Such a sense of how knowledge does its work exists in biomedical science; not in global health.

Much of the edifice of academic global health is built on the assumption that the primary goal is to identify universal truths; to add to a central pool of knowledge $e^{4-6}$ for example, on the biology of a virus, in the quest for a vaccine. The propensity for the universal in global health-often apparent in the declared aim of research papersstems partly from its biomedical and colonial origins. ${ }^{7-10}$ To be rigorous is therefore a cliché that demands universal truths, or external validity, or a default to uniform and standardised methods, metrics, indicators, measures, around the world. But truth, in such a centralised or universal sense is typically not the goal in the quest for equity. ${ }^{4-6}$ What most often matters is finding contingent, circumstantial or particular truths about what it takes to achieve equity at a place and time-and subsequently, finding regularities; finding the universal in particular. ${ }^{4-6}$ If we want to serve our mission, our efforts must begin with a concern for how knowledge leads to equity.

The impression you get from our literature-if all you read are research papers in elite journals-is very likely that equity in global health comes about primarily through discrete, episodic, one-off events; macroinnovations, or (often externally introduced) measurable, tangible, time-bound interventions, which function independent of one another and of context, the effects of which can be seen from a distance. ${ }^{3}{ }^{8-12}$ You may also get the impression that large or multisite studies are inherently more valuable than small or single site studies; or that there is virtue in adopting methods and measures whose primary purpose is to simplify complex realities. This literature is like the misleading tip of an iceberg. What remains buried beneath the surface are the day-to-day uses of knowledge for change by actors at different scales of organisation. The literature reads 
like a conversation to which the primary participants were not invited. ${ }^{38-12}$

The academic global health literature marginalises a lot of conversations that should be primary-for example, on the role that social learning plays in how knowledge is used to achieve equity ${ }^{13-15}$; equity in (the circumstances that create) health within and between countries. It is time to look again at our assumptions of the primary purpose of our literature, and to consider what a reordering of those assumptions may mean for how the literature itself is put together. The status quo reflects a pervasive misordering of value. ${ }^{10}$ It is time to reorder our working assumptions so that they begin with a (rebuttable) presumption that there are primary uses, users and producers of knowledge that our literature must serve first and foremost. This essay presents a principle on which we may seek to construct such a different order for our literature; an order that begins with how knowledge is used to achieve equity.

\section{THE PRINCIPLE OF SUBSIDIARITY}

The word 'subsidiarity' comes from subsidium, a Latin term which originated in the Roman military. It was used to describe the third line of soldiers, "who would only join in a battle if the powers of the two front lines were insufficient'. ${ }^{16}$ The military connotation of subsidium has faded over time. The term now refers to help, assistance, support or aid-the kind that one would not need or receive under ideal conditions, or the kind that will only be offered based on request. ${ }^{16-18}$ In its modern usage in social and political philosophy, the word 'subsidiarity' is used in relation to an ethical principle-that is, the principle of subsidiarity. The principle holds that decisions about efforts to help others and to attain the common good (eg, by using knowledge to achieve equity in global health) should, by default, take place at the smallest or most proximate level/scale of organisation possible, and only when necessary at a larger or more distant level/ scale of organisation. ${ }^{16-19}$

Evoked as a safeguard against (over-)centralisation, subsidiarity is a priority principle for relations between governing entities. Subsidiarity means (until proven otherwise) smaller/proximate units take precedence over larger/distant units-individual nations over supranational entities to which they belong, subnational over national governments, communities over governments, and families over communities. The principle of subsidiarity predates its explicit use. Historically, subsidiarity was implicit in the formation and relations within and among loose confederations of Greek and Yoruba city states. ${ }^{20-23}$ In global health, there is multiplicity of proximate-distant (or primary-subsidiary) relations (between/among social, technical and political entities within and beyond jurisdictional boundaries). The principle of subsidiarity provides a practical basis for governing aspects of these relations; especially those that pertain to the uses of knowledge.
The case for adopting the principle of subsidiarity to reorder our assumptions about the uses of knowledge can be made on two inseparable grounds-on the practical (eg, effectiveness and efficiency) and moral (eg, equity and justice) benefits of acting close to the ground, close to the issues and close to the people. ${ }^{16-19}$ The practical benefits include that subsidiarity allows proximate actors with optimal knowledge of problems to take initiative; to experience the consequences of their actions; and to revise their theories and inform subsequent iterations of action based on local information, feedback and observed regularities. ${ }^{16-192425}$ By promoting proximate initiative and action at smaller scales or by diverse smaller entities, subsidiarity also promotes plurality and multiplicity of forms-which in turn increases opportunities for learning (within and across such small units) and for resilience to shocks (given back up and network effects across small units). ${ }^{182425}$

The moral benefits of subsidiarity mirror its practical benefits, as moral proximity follows physical proximity. Moral proximity implies accountability to oneself and to one's community, with a high stake in ensuring the success of collective efforts or initiatives. Putting one's own proximate (including tacit and informal) knowledge to use can inspire one's confidence in its value. With proximate action and use of knowledge, actors see how their (often collective) efforts help to promote the common good. This experience can then help actors achieve the deeply human and existential need to be useful, to avoid social alienation and dependency, to exercise agency and to gain the sense of dignity and meaning that comes with shaping one's own destiny. ${ }^{24}$ The moral necessity of the principle of subsidiarity is so pressing that it has been described as 'a grave evil' and 'an injustice' to assign to a distant or subsidiary entity what a proximate or primary entity can do. ${ }^{26}$

On the road to equity, knowledge is primarily produced or used by proximate actors to generate small wins-that is, continuous day-to-day 'organic' micro-innovations. ${ }^{3} 1214$ On the other hand, subsidiary production or use of knowledge is often about large wins, typically episodic, 'surgical' or major innovations, designed or enacted at a distance. ${ }^{312}$ Proximity focusses attention on small wins. After all, large wins are really a cumulation of those small wins; of minor changes that result from ongoing learning. Small wins require less coordination to implement, and they are more structurally resilient compared with single large wins. Each small step inspires confidence in the possibility of success in the next step. These steps can be assembled in endlessly varying combinations from place to place, from time to time. So, what may appear to a distant, subsidiary actor as the 'next logical step' or 'next solvable problem' will typically diverge significantly from that of a proximate, primary actor. $^{12} 14$

Applied to the uses of knowledge, the principle of subsidiarity may be distilled into four precepts ${ }^{16-19}$ along the following lines: (1) primary units must have the 


\begin{tabular}{lll}
\hline Proximate/Local/Primary & "Emancipator” & "Plumber" \\
\hline Distant/Foreign/Subsidiary & "Engineer" & "Professor" \\
\hline
\end{tabular}

Figure 1 Units of knowledge use(r)s in global health.

Note: the distinctions drawn here are partly inspired by Dekker (2020) ${ }^{27}$ and Abimbola (2019). ${ }^{3}$

freedom, opportunity and responsibility to produce, use and rely on their own knowledge, and to indicate when they need the help of subsidiary units; (2) subsidiary units must only provide help when requested, respecting the presumptive authority of primary units in relation to knowledge, unless primary units are evidently so weak that they are unable to seek help; (3) subsidiary units must direct requested or offered help towards the goals of primary units and not their own goals; and (4) there must exist built-in structures to govern the engagement with subsidiary units, to decide the terms of engagement and when to modify or (dis) continue help, so that subsidiary units do not usurp or undermine the role of primary units and so that primary units do not end up overly dependent on subsidiary units.

\section{EMANCIPATOR, ENGINEER, PLUMBER, PROFESSOR}

How then may we distinguish primary from subsidiary uses (or units of users or producers) of knowledge? The principle of subsidiarity suggests that academic research is subsidiary to knowledge from the practice arena; policy designers are subsidiary to implementers; what is episodic is subsidiary to what is day to day; and distant decision-making is subsidiary to proximate decisionmaking. These distinctions suggest four uses (or units) of knowledge (figure 1). ${ }^{27}$ Two uses/units are primary: emancipators (people using knowledge to transform the structural determinants of their own health) and plumbers (implementers using knowledge for change). Two uses/units are subsidiary: engineers (policy designers using knowledge from primary units) and professors (knowledge-mongers). Each use/unit may exist in an individual, group or organisation. Quite like fractals, the units of four form a knowledge ecosystem that is present at different scales of organisation (figure 2).

Emancipators are activists-eg, as individual activists, teams of campaigners, women's groups or civil society organisations. They use knowledge to seek to construct a new reality for themselves, to demand and create ideal conditions (economic, social, political, gender) for themselves and alter the social structures and rules that disadvantage them; ${ }^{28}$ rules made locally or at a distance. In the process, they also produce knowledge. On the other hand, broadly accepting of the status quo, plumbers work within existing systems. Plumbers use and produce knowledge day-to-day, as they bring about incremental change through service delivery-eg, as individual bureaucrats, teams of service providers, NGOs or ministries of health. As primary units, plumbers and emancipators are together responsible for the vast bulk of change in global health. ${ }^{12-1527-32}$ They make progress in small wins. They learn from these small wins, and from small losses too. They learn by doing.

Engineers design policies, programmes and systems, or they create the overarching framework within which plumbers perform these roles and their own roles. ${ }^{27} 3334$ Emancipators seek to alter the designs of engineers. Engineers have power or align with power. They are considered 'activist' insofar as they can use their power to construct emancipatory realities. Emancipators seek to ensure such outcomes. Engineers are visible. They attract the attention of professors. Too much of our literature is aimed at engineers, as if change emanates primarily from the intercourse between political and academic elite-as if the literature is just an instrument of power. The knowledge needs of (and the knowledge produced or held by) emancipators and plumbers go unacknowledged, as if they do not exist. Whereas the vast bulk of the literature should be written for and by emancipators and plumbers. If this appears far-fetched, it is because the status quo is not fit for purpose.

Professors can be individual academics, research or data teams or groups, think tanks, academic institutes or universities. They may also be the research or data unit of an organisation of emancipators or plumbers. Professors share knowledge through publications and teaching and activities that help to connect a system, any system, 'to more of itself'. ${ }^{35-37}$ They also repackage and reframe existing knowledge, and sometimes generate new knowledge. To contribute to equity, professors may seek to undo assumptions and mindsets that hold back equity or develop analytical tools to better define and solve problems. ${ }^{38}$ Some, in an ivory tower sense, may be uninterested in equity, and curate seemingly useless knowledge, some of which may become useful for equity. But perhaps the most direct-and primary-way in which professors use knowledge for equity is by helping to connect a system to more of itself; by moving knowledge within and across time and place. ${ }^{35-37}$

The academic global health literature has been a space for professors. It is time for that to change. What engages the attention of professors is not necessarily 


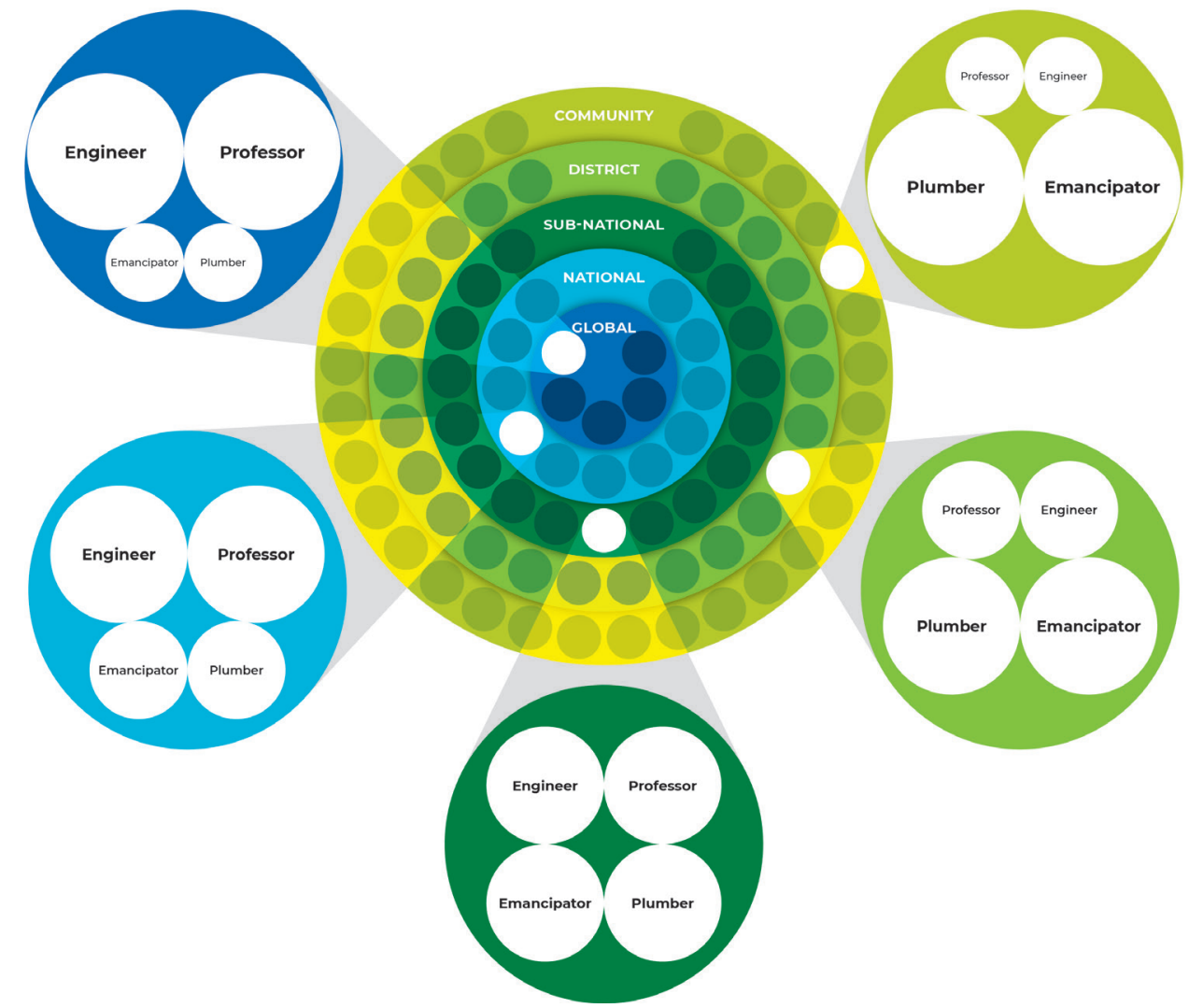

Figure 2 Concentric rings of knowledge use(r)s in global health.

Note: this figure shows (1) examples of the scales of organisation at which knowledge is used for equity (ie, the five concentric rings); (2) the spaces in which the knowledge is used (ie, the small circles that line the concentric rings); and (3) the four use(r) $\mathrm{s}$ or units of knowledge which are represented as four labelled circles within each small circle. Note that the size of the primary use(r)s or units (ie, emancipators and plumbers) is larger closer to the community 'ring', while subsidiary use(r)s or units (ie, engineers and professors) is larger closer to the global 'ring'.

what advances equity in global health. Professors are party to equity when they are part of learning processes among and between plumbers and emancipators (with or without engineers), purposefully helping to connect units to one another. They may be professoremancipators (scholar-activists) ${ }^{29} 3^{39-41}$ or professorplumbers (scholar-implementers). ${ }^{42-44}$ They may work directly with engineers to ensure that their designs are based on knowledge produced or held by plumbers and emancipators. ${ }^{45-48}$ Even then, engineers need to aggregate a plurality of interests and knowledge. ${ }^{49-51}$ Professors may help to connect different interests and knowledge by facilitating platforms for deliberation among groups of emancipators and groups of plumbers; or between emancipators and plumbers. ${ }^{52}$

Equity is political. Engineers and emancipators are inevitably political. Even plumbers will sometimes have to be emancipators. ${ }^{53-56}$ Professors will often need to be just as political. Uses and users of knowledge can also be fluid. An emancipator for a cause can be a plumber or engineer for another. An engineer for a design may be a plumber or emancipator for another. But the use of knowledge by engineers for 'big wins' is so visible, it is far too often the focus of professors. ${ }^{38-12}$ The use of knowledge by plumbers gets a lot of their attention too, but nowhere near enough. Emancipators get even much less attention. The primary uses of knowledge (by plumbers and emancipators) often go unseen, in part because despite small wins and the learning that result from them, day by day nothing appears to change. ${ }^{12}$ In many instances, change is more apparent in hindsight. Much more seen is the episodic work of professors (aimed at engineers) and of engineers (reported by professors).

\section{INJUSTICES IN THE USES OF KNOWLEDGE}

There are countless spaces within which knowledge may be used to connect a system to more of itself. Such spaces exist at different scales of organisation-communities, districts, subnational or national entities, and the globe (figure 2). Inside each space, actors hold, produce and use knowledge as primary units, sometimes with the help of subsidiary units. Knowledge from small wins and small losses may get shared within the space in which it is produced—or shared between spaces at the same scale of organisation (eg, between districts or between countries) or between spaces at different scales of organisation (eg, between a district and a community, or between a country and a global entity). The principle of subsidiarity ${ }^{16-19}$ 
suggests that the flow of knowledge should be to circulate within spaces, serve proximate spaces and primary units before it is put to subsidiary uses. Notably, the four precepts of the principle of subsidiarity ${ }^{16-19}$ suggest how we might define and limit injustices in the uses of knowledge.

First, injustices occur when subsidiary units fail to defer and default to primary units as primary producers and holders of knowledge. Or when subsidiary units do not allow primary units to make the most of the knowledge that they produce and hold. It manifests when subsidiary units default to a deficit-based approach to knowledge rather than asset-based approaches to knowledge ${ }^{57}$ (eg, reckoning with existing knowledge, efforts and small wins). It manifests in failure to minimise the need for subsidiary units, that is, by not investing in platforms that allow primary units to learn for themselves, circulate learning from small wins and connect to more of themselves (eg, through routine data, deliberation or after-action review) ${ }^{58}$ To limit such injustices, it may be necessary to mandate that any help provided by subsidiary units should be provided in a way that does not take away from (but instead reinforces) the capacity and opportunity of primary units to learn for themselves.

Second, injustices occur when subsidiary units presume to have the right to help primary units to produce or use knowledge when there is no explicit request to do so and there is no evident lack of the capacity to make such a request. The effect may manifest in usurping the ability of primary units to learn for themselves and develop their own learning structures, as they iteratively produce and use knowledge to generate small wins. It may manifest in the failure to see that the only help worth offering without explicit request are subsidiary-for example, help that offers platforms to facilitate the flow of existing knowledge, to connect a system to more of itself, to its neighbours and to similar entities elsewhere ${ }^{59}$ To limit these injustices, perhaps ethics approval for any help provided by subsidiary units should require evidence of request from primary units (eg, through a representative process), or of inability to request help, or that the help being offered is only subsidiary.

Third, injustices occur when subsidiary units prioritise or privilege their own perspectives, concerns or needs (eg, what is 'innovative' or what is 'new knowledge') over helping to connect a system to more of itself. This may manifest in a tendency to focus energies on subsidiary activities even when primary units request help-for example, in acting as if publication is a primary goal of such an effort, even though the knowledge in publications pales in comparison to whatever knowledge is produced while assisting plumbers and emancipators, or even engineers. ${ }^{3}$ Perhaps academic journals, institutions and funders should insist that knowledge ought to have done its primary work in the world before it is allowed to be published or used for other subsidiary purposes. This means that research papers will become as much about 'new findings', as they are about the lessons learnt while the new findings did their primary work-that is, while being used to connect a system to more of itself.

Fourth, injustices occur when there are no effective structures to govern the terms of engagement between subsidiary and primary units-to avoid subsidiary units undermining primary units and to avoid primary units becoming overly dependent on subsidiary units. This can be, for example, a committee to review, modify or discontinue engagement, to ensure that subsidiary units do not unilaterally disengage, and to guide what to do with any knowledge that is generated as part of the engagement, and perhaps what gets published, how and where. The committee may recommend that knowledge intended for primary uses should be presented concretely, while knowledge intended for subsidiary uses should be presented in an abstract way that allows insights to travel. ${ }^{2}$ The committee may approve publications, their authorship and intended audience. The committee may insist on local outlets and forms that are readily accessible to the relevant primary units.

The academic global health literature needs to develop just and inclusive ways of reckoning with knowledge, of all kinds-especially from and for plumbers and emancipators. The literature must open itself to different ways of sharing knowledge. It must seek to approximate available knowledge. The lack of representativeness of authorship in academic global health must be understood also in terms of the lack of representativeness of the knowledge that is available in the literature. The literature needs to begin from premises that default and defer to the practice-based knowledge produced, used and held by plumbers and emancipators; and at proximate scales of organisation. Professors will need to invest as much time, energy and resources in plumbing and emancipation, in helping to connect systems to more of themselves and strengthening routine data systems, as they do in initiating research. Having such data systems will make redundant much of what counts as global health research.

\section{CONCLUSION}

The assumptions that underpin our system of prestige and value in academic global health are inherently extractive. These assumptions make the literature read like subsidiary actors speaking to one another in echoes about subsidiary actions. They lead us in the paths of injustice. In thinking that the value of a study is a publication, and that what is not published is not known, we have been unjust. In choosing to focus on the episodic at the expense of the day-to-day, we have been unjust. In failing to prioritise what is primary over what is subsidiary in our uses of knowledge, we have been unjust. In failing to see, share and publicise small wins, we have been unjust. In reinforcing the notion that external validity and standardised measures come before local use and 
local relevance, we have been unjust. In thinking that our primary role is to produce new knowledge rather than helping to connect a system, any system, to more of itself, we have been unjust.

This is not to pitch one use of knowledge against another. The principle of subsidiarity is not so much about what should be done or not done, as it is about what should be prioritised. It is a call to rethink our relative focus, emphasis, priority, gaze. It is a call to default to the local gaze; to take the imaginative leap that allows a foreign (or subsidiary) actor to assume, speak or write from a local (or primary) pose. It is a call to reorder the hierarchy of rigour and value that shape our assumptions about knowledge; to recognise where the vast bulk of knowledge that is used to advance equity in global health is to be found. It speaks to an intellectual deficit in academic global health. ${ }^{60}$ This deficit overlaps with the colonisation problem, but not completely-there is distinct crescent in the Venn diagram of their overlap. The principle of subsidiarity shows us how we default to injustice-it also points to an alternative vision for academic global health, and its literature.

Twitter Seye Abimbola @seyeabimbola

Acknowledgements Many thanks to my friends, students and colleagues who listened to me talk about the ideas in this essay as they developed, who suggested references or readings, and who read and critiqued previous drafts-in person, on Twitter, by email and on Zoom.

Funding The author is currently supported by the National Health and Medical Research Council (NHMRC) of Australia through an Overseas Early Career Fellowship (APP1139631)

Competing interests None declared.

Patient consent for publication Not required.

Provenance and peer review Not commissioned; internally peer reviewed.

Data availability statement There are no data in this work

Open access This is an open access article distributed in accordance with the Creative Commons Attribution Non Commercial (CC BY-NC 4.0) license, which permits others to distribute, remix, adapt, build upon this work non-commercially, and license their derivative works on different terms, provided the original work is properly cited, appropriate credit is given, any changes made indicated, and the use is non-commercial. See: http://creativecommons.org/licenses/by-nc/4.0/.

ORCID iD

Seye Abimbola http://orcid.org/0000-0003-1294-3850

\section{REFERENCES}

1 Hayek FA. The use of knowledge in society. Am Econ Rev 1945;35:519-30.

2 Abimbola S. On the meaning of global health and the role of global health journals. Int Health 2018;10:63-5.

3 Abimbola S. The foreign gaze: authorship in academic global health. BMJ Glob Heal 2019;4:e002068.

4 Rutter H, Savona N, Glonti K, et al. The need for a complex systems model of evidence for public health. Lancet 2017;390:2602-4.

5 Greenhalgh T. Will COVID-19 be evidence-based medicine's nemesis? PLoS Med 2020;17:e1003266.

6 Ogilvie D, Bauman A, Foley L, et al. Making sense of the evidence in population health intervention research: building a dry stone wall. BMJ Glob Health 2020;5:e004017.

7 Affun-Adegbulu C, Adegbulu O. Decolonising global (public) health: from Western universalism to global pluriversalities. BMJ Glob Health 2020;5:e002947.
8 Biehl J, Petryna A. Peopling global health. Saude soc. 2014;23:376-89.

9 Biehl J, Petryna A. Critical Global Health. In: Biehl J, Petryna A, eds. When people come first: critical studies in global health. Princeton, NJ: Princeton University Press, 2013: 1-20.

10 Richardson ET. Epidemic illusions: on the coloniality of global public health. Cambridge, MA: MIT Press, 2020.

11 Storeng KT, Béhague DP. "Playing the numbers game": evidencebased advocacy and the technocratic narrowing of the Safe Motherhood Initiative. Med Anthropol Q 2014;28:260-79.

12 Weick KE. Small wins: redefining the scale of social problems. Am Psychol 1984;39:40-9.

13 Sheikh K, Agyepong I, Jhalani M, et al. Learning health systems: an empowering agenda for low-income and middle-income countries. Lancet 2020;395:476-7.

14 Ellerman D. Hirschmanian themes of social learning and change. policy research working paper series. No. 2591. Washington, DC: The World Bank, 2001.

15 Schon DA. Hirschman's Elusive Theory of Social Learning. In: Schon DA, Rodwin L, eds. Rethinking the development experience: essays provoked by the work of Albert O Hirschman. Washington, DC: Brookings Institution Press, 1994: 67-95.

16 Gosepath S. The Principle of Subsidiarity. In: Follesdal A, Pogge T, eds. Real world justice: grounds, principles, human rights, and social institutions. Dordrecht: Springer Netherlands, 2005: 157-70.

17 Cahill M. Theorizing subsidiarity: towards an ontology-sensitive approach. Int J Const Law 2017;15:201-24.

18 Höffe O. Subsidiarity as a principle in the philosophy of government. Reg Fed Stud 1996;6:56-73.

19 Chaplin J. Subsidiarity: the concept and the connections. Ethical Perspect 1997:4:117-30.

20 Usman A, Falola T. The Yoruba from prehistory to the present. Cambridge: Cambridge University Press, 2019.

21 Adelusi-Adeluyi A, Bigon L. City Planning: Yorùbá City Planning. In: Selin $\mathrm{H}$, ed. Encyclopaedia of the history of science, technology, and medicine in non-Western cultures. Dordrecht: Springer Netherlands, 2008: 1-7.

22 Rufus Davis S. The federal principle: a journey through time in quest of meaning. Berkeley and Los Angeles: University of California Press, 2021: 258

23 Roy J. The urban layout of Megalopolis in its civic and confederate context. Br Sch Athens Stud 2007;15:289-95.

24 Drew J, Grant B. Subsidiarity: more than a principle of decentralization - a view from local government. Publius 2017;47:522-45

25 Abimbola S, Baatiema L, Bigdeli M. The impacts of decentralization on health system equity, efficiency and resilience: a realist synthesis of the evidence. Health Policy Plan 2019;34:605-17.

26 Pope Pius XI. Quadragesimo anno (on social reconstruction). Vatican City: Libreria Editrice Vaticana, 1931.

27 Dekker E. On emancipators, engineers, and students: the appropriate attitude of the economist. Rev Austrian Econ 2020;33:55-68.

28 Galtung J. Violence, peace, and peace research. J Peace Res 1969;6:167-91.

29 Gumbonzvanda N, Gumbonzvanda F, Burgess R. Decolonising the 'safe space' as an African innovation: the Nhanga as quiet activism to improve women's health and wellbeing. Crit Public Health 2021:9:1-13.

30 Levitt SD, List JA, Syverson C. Toward an understanding of learning by doing: evidence from an automobile assembly plant. J Polit Econ 2013;121:643-81.

31 Hendel I, Spiegel Y. Small steps for workers, a giant leap for productivity. Am Econ J Appl Econ 2014;6:73-90.

32 Askew DA, Brady K, Mukandi B, et al. Closing the gap between rhetoric and practice in strengths-based approaches to Indigenous public health: a qualitative study. Aust N Z J Public Health 2020;44:102-5.

33 Erasmus E. The use of street-level bureaucracy theory in health policy analysis in low- and middle-income countries: a metaethnographic synthesis. Health Policy Plan 2014;29:iii70-8.

34 Abimbola S. Health system governance: a triangle of rules. BMJ Glob Heal 2020;5:e003598.

35 Wheatley MJ, Kellner-Rogers M. Bringing life to organizational change. J Strateg Perform Meas 1998:5-13.

36 Wheatley MJ. Bringing Schools Back to Life: Schools as Living Systems. In: Duffy FM, Dale JD, eds. Creating successful school systems: voices from the University, the field, and the community. Norwood, MA: Christopher-Gordon Publishers, 2001: 3-19.

37 Wheatley MJ, Frieze D. Lifecycle of emergence: using emergence to take social innovation to scale. Kosm J 2015;24:45-7. 
38 Whyle E, Olivier J. Social values and health systems in health policy and systems research: a mixed-method systematic review and evidence MAP. Health Policy Plan 2020;35:735-51.

39 Eschle C, Maiguashca B. Bridging the Academic/Activist divide: feminist activism and the teaching of global politics. Millennium 2006;35:119-37.

40 Musolino C, Baum F, Freeman T, et al. Global health activists lessons on building social movements for health for all. Int $J$ Equity Health 2020;19:116.

41 Campbell $\mathrm{C}$, Burgess R. The role of communities in advancing the goals of the movement for global mental health. Transcult Psychiatry 2012;49:379-95

42 Irimu G, Ogero M, Mbevi G, et al. Approaching quality improvement at scale: a learning health system approach in Kenya. Arch Dis Child 2018;103:1013-9.

43 Ropa B, Flint J, O'Reilly M, et al. Lessons from the first 6 years of an intervention-based field epidemiology training programme in Papua New Guinea, 2013-2018. BMJ Glob Heal 2019;4:e001969.

44 Young T, Shearer JC, Naude C, et al. Researcher and policymaker dialogue: the policy BUDDIES project in Western Cape Province, South Africa. BMJ Glob Heal 2018;3:e001130.

45 RESYST/DIAHLS Learning Site Team. Learning sites for health system governance in Kenya and South Africa: reflecting on our experience. Health Res Policy Syst 2020;18:44.

46 Montilla P, Merzagora F, Scolaro E, et al. Lessons from a multidisciplinary partnership involving women parliamentarians to address the overuse of caesarean section in Italy. BMJ Glob Heal 2020;5:e002025.

47 McAteer J, Di Ruggiero E, Fraser A, et al. Bridging the academic and practice/policy gap in public health: perspectives from Scotland and Canada. J Public Health 2019;41:632-7.

48 Uzochukwu B, Onwujekwe O, Mbachu C, et al. The challenge of bridging the gap between researchers and policy makers: experiences of a health policy research group in engaging policy makers to support evidence informed policy making in Nigeria. Global Health 2016;12:67.
49 Belghiti Alaoui A, De Brouwere V, Meessen B, et al. DecisionMaking and health system strengthening: bringing time frames into perspective. Health Policy Plan 2020;35:1254-61.

50 Bonvin J-M, Laruffa F. Deliberative democracy in the real world, the contribution of the capability approach. Int Rev Sociol 2018;28:216-33.

51 Salais R. Deliberative democracy and its informational basis: what lessons from the Capability Approach. In: De Munck J, Zimmermann B, eds. La liberté Au prisme des capacités Amartya SEN au-del Du libéralisme. Raisons pr. Paris: Editions de I'EHESS, 2008: 297-326.

52 Bryant T. Role of knowledge in public health and health promotion policy change. Health Promot Int 2002;17:89-98.

53 Schaaf M, Warthin C, Freedman L, et al. The community health worker as service extender, cultural broker and social change agent: a critical interpretive synthesis of roles, intent and accountability. BMJ Glob Health 2020;5:e002296.

54 Abers RN. Bureaucratic activism: pursuing Environmentalism inside the Brazilian state. Lat Am Polit Soc 2019;61:21-44.

55 O'Sullivan D. Power, politics and the street-level bureaucrat in Indigenous Australian health. J Sociol 2016;52:646-60.

56 Brown TM, Fee E. Rudolf Carl Virchow: medical scientist, social reformer, role model. Am J Public Health 2006;96:2104-5.

57 Morgan A. Revisiting the asset model: a clarification of ideas and terms. Glob Health Promot 2014;21:3-6.

58 Ghaffar A, Swaminathan S, Sheikh K, et al. Implementation research is crucial to countries' efforts to strengthen learning health systems. Health Policy Plan 2020;35:ii4-6.

59 Bailie J, Cunningham FC, Bainbridge RG, et al. Comparing and contrasting 'innovation platforms' with other forms of professional networks for strengthening primary healthcare systems for Indigenous Australians. BMJ Glob Heal 2018;3:e000683.

60 Abimbola S, Pai M. Will global health survive its decolonisation? Lancet 2020;396:1627-8. 